\title{
The Limit and Possibilities of Unification Education as Peace Education beyond Division in South Korea
}

\author{
Soon-Won Kang
}

\begin{abstract}
In this article, the limits and possibilities of Korean unification education is critically examined and compared with the peace process on the Korean Peninsula for overcoming division from the perspective of peace education. For the purpose of becoming a single unified Korea, the direction of unification education has been presented within a hostile frame to cultivate attitudes and values for its own sake. Peace education in a divided society refers to a collective effort to transform the situation of hostile division into peaceful coexistence and rapprochement. In this context, unification education for overcoming the division of the Korean Peninsula should be established as the subject of critical peace education according to the global standards of Sustainable Development Goal 4.7.
\end{abstract}

Keywords unification education, division of Korean Peninsula, peace process, peace education, Sustainable Development Goal 4.7

\section{Introduction}

The people of the Korean Peninsula, including the Republic of Korea (ROK, South Korea) and the Democratic People's Republic of Korea (DPRK, North Korea), are anxious and worried that war might break out. As such unrest dominates the political atmosphere, culture, and media, peace is armed with the logic of national prosperity and military power and reflected in the educational culture of schools. Assuming that extreme school violence is related to this perspective of peace by force, the dehumanization of school violence and the high rate of suicide among youths can be attributed to a school environment in which authoritarian power is the preferred method of solving problems (Chung 2016). For instance, a school climate in which everyone is trying to become a jjang (boss or informal leader), those who seem vulnerable are easily blamed by calling them aeja (an acronym for the disabled), or calling those who have different ideas 
bbalgaengi (Commie) is non-peaceful (Kwon, Kristjansson, and Walker 2016).

For this reason, in 2011, the Gyeonggi Metropolitan Education Authority declared that the direction of peace education, an issue faced by the education sector, is connected with unification education through the Charter of Gyeonggi Peace Education. From the peace educational perspective, the direction of unification education was made clear by the Charter:

The spirit and value of peace is the ultimate goal of education and ideals of universal humanity. Peace is not learned by itself, but taught in respectable and respected societies, and this is transferred to the next generation...In unification education, it is fundamental to recognize the absolute importance of peace in the international relations of the Korean Peninsula and East Asia, and develop a responsible historical attitude for peaceful coexistence and peaceful reunification of the Korean Peninsula (Gyeonggi Metropolitan Education Authority 2011).

Since unification education in the Charter did not coincide with the direction of the Lee Myung-Bak administration, it created confusion in schools. Nevertheless, in regards to the fact that the Peace Education Charter set the direction for peace and security on the Korean Peninsula through the unification education at the level of a provincial education authority, it is worthwhile to debate the relationship between existing unification education and peace education.

There are discussions on whether unification education can be interpreted as a category of peace education. In general, peace education is defined as education for peace, education by peace, and education of peace. That is, peace education is comprehensive education that covers the peaceful attitudes and values, peaceful methods, and the nature of peace (Reardon 2001). It is the most meaningful method to deal with peace by peaceful means (Galtung 1996). Thus, it is difficult to identify unification education, which is anti-communist and aims at peacebuilding by force, with other forms of universal peace education. Therefore, it has been argued that unification education, which seeks to build peace through force, should be transformed into peace education which strives toward peace and security on the Korean Peninsula through peaceful means (Kang 2000; Han 2001; Park 2004; Park 2006; Chung and Kim 2007; Ham 2015).

Overall, unification education is a subject area where the color of the regime has been reflected since the division of the Peninsula. Therefore, as the author posits that changes in the peace process on the Korean Peninsula have the most meaningful effect on unification education, the contents and form of unification education are inevitably subjected to change due to fluctuations in inter-Korean relations and international relations in Northeast Asia. In this article, the limits and possibilities of Korean unification education is critically examined and compared with the peace process of the Korean Peninsula for overcoming division from the perspective of peace education. 
This study was conducted through a socio-historical analysis of unification education based on data analysis of moral education, the Road to Unification by Defeating Communism textbooks, and data from in-depth interviews with two experts of unification education. To protect identities, the two interviewees will be referred to as A and B; A is a professor who has been working in the field of unification education for more than fifteen years, and B has been a teacher in charge of moral education in high schools for twenty years. Both agreed to have their responses used as data for research.

\section{Definition of (Re)Unification Education}

During the imperial period, the world was divided into imperialist and colonized nations. At that time, the liberation wars of the colonized led to national independence, and after World War II, so-called AALA (Asia, Africa, and Latin America) third world countries in the Southern Hemisphere became sovereign nations. But they confronted considerable difficulties due to the new global environment organized based on the Cold War order and fragile political leadership. Nevertheless, such trouble was deemed a result of innate qualities such as tribalism and lack of progress rather than due to invasion by and disharmony among the powerful countries (Mamdami 2012).

As President Moon Jae-in declared during the celebration of Liberation Day on August 15, 2017, "division is an unfortunate legacy of the colonial period in which we could not determine our destiny in the midst of the Cold War" (Moon 2017). As soon as the two Koreas were liberated from Japanese colonial rule, they were divided during the process of reorganization into the Cold War order after the Second World War. The Korean War that followed then expanded into a world war in which the two forces of the Cold War collided. The Korean Peninsula is the world's most notorious powder keg where two hostile ideologies are still in conflict. According to Jin (2018), the Japanese colonization of Korea was the result of the victory of the Japanese maritime forces, and the current crisis of the Korean peninsula is seen as the emergence of U.S. maritime power. Even Galtung (1985) criticized that, in the same vein, the division of the Korean Peninsula was a superpower convenience and a clear expression of occidental racism. Cummings (1986) also argued that the Korean War had a micro-agent character in that the problem of the Korean Peninsula is within the context of the Cold War system and the solution should be found at the global level.

However, after liberation, the dominant political forces in South Korea have been promoting a national unification ideology of "Our Nation is One" (Kim 2005), and promoting the sentiment of national unification while shying away from investigating the roots of division (M. Kang 2013). In particular, in a situation where the responsibility for the Korean War, which caused enormous 
damage, is shifted unilaterally onto the other party, South and North Korea were perceived separately and mutual exchanges were entirely forbidden. After the Korean War, authoritarian governments established on both sides of the Korean Peninsula remained hostile to one another. As a result, South Korea has emphasized the cultural code of "Our Wish is Unification," while making the division a means of maintaining the regime (Baek 1998), and promoting unification by force as a means to enhance its military alliance with the United States. As "the unity of becoming one by force" ideology becomes predominant, the system conflict between the two Koreas is likely to continue to increase.

Although South and North Korea concurrently joined the United Nations (UN) as individual sovereign nation-states in 1991, Article 3 of the Constitution of the ROK states that the territory of the ROK shall be the entire peninsula and its annexed islands. And Article 4 states that it aims for peaceful unification based on a free democratic order. In the Constitution of the DPRK, Article 9 states that the DPRK strengthens the people's regime in the northern part of the Peninsula and proposes a socialist unification that strives to achieve the full victory of socialism trough three revolutions of ideology, technology, and culture, and to struggle for the realization of national reunification on the principle of independence, peaceful unification, and national unity. The content and direction of unification that presupposes such different political orientations present a hostile frame to the unification education process.

In fact, the Unified Silla (AD 668) dynasty was the first to use the term "unification" on the Korean Peninsula. And since a unified dynasty existed on the Korean Peninsula through the Goryo and Chosun periods up until the colonial period, there was no need to bring up the term "unified nation" (Ham 2003). Since the political base of the independence movement under Japanese colonial rule was based on anti-Japanese nationalism, the division into South and North after liberation in 1945 was difficult to accept, and this made "national unification" a common political slogan. However, as the international situation surrounding the Korean Peninsula was discussed at the Yalta, Potsdam, and Moscow trilateral meetings, the Cold War system at the global level led to the division of the Korean Peninsula. Shortly after division, North Korea instigated the Korean War in 1950 for the purpose of socialist unification, resulting in three years of unrelenting destruction. Despite this, the United States, China, and North Korea signed the armistice agreement in July 1953 and the ceasefire remains in effect until today. Thus, the division of the Korea Peninsula is defined as a division resulting from the Cold War (Galtung 1985; Cumings 1986; Wada 1999). In this context, unification education on the Korea Peninsula should be established as a subject of critical peace education with a global dimension (Kim 1988; Lee 2017).

However, unification education is done within the framework of the national curriculum of the ROK. Until 2012, the theme of unification education 
was to be handled within the framework of the state designated textbooks. The formal definition of unification education is noted in Article 2 of the Unification Education Support Act: unification education refers to education designed to cultivate the values and attitudes necessary for achieving unification based on belief in a free democracy, national community consciousness, and sound security. This is based on Article 3 of the same law, which states that 1) unification education should defend the free democratic basic order and aim for peaceful unification, and 2) unification education shall not be used for personal or partisan purposes (Ministry of Unification 2013). According to the definition provided by the Unification Education Support Act, unification education is education to cultivate the righteous values and attitudes for unification rather than to deal with proper knowledge about unification. Since unification education presupposes political neutrality that it is not used for personal or partisan purposes, critical thinking cannot help but be omitted in terms of why the Peninsula should be unified, what the roots of division are, what kind of unified state should be built, how unification should progress, what should be done to prepare for unification, and how education should be changed.

Unification education without critical awareness is not peace education in the universal sense. Therefore, with respect to the definition of unification education as integrated education for resolving conflicts originating from division, it is necessary to overcome the antagonistic image of the North Korean regime and expand contact to create an image of a mutually beneficial neighboring community by utilizing a postcolonial lens which questions whether or not the Peninsula had to be divided immediately after colonialism. It is obvious that, through the establishment of a good reciprocal relationship with North Korea to establish a peace system on the Korean Peninsula, the education needed for living together beyond division is to trace historical progress of peaceful unification (Kim 1997; Chung and Kim 2007; S. Kang 2013).

\section{Peace Education beyond Division on the Korean Peninsula}

The Korean Peninsula is a region overwhelmingly dominated by the Cold War system and the logic of peace by force, but South Korean society is an exceptional example of the possibility of democratic change through people power. In spite of such unfortunate political circumstances including being colonized, divided soon after liberation, tortured by civil war, and politically oppressed by authoritarian regimes, the citizens of South Korea eventually achieved peace and prosperity for the future throughout democratization movements.

Reardon (1988) asserts that the core concept of peace education is to reduce and ultimately eliminate violence. Peace education emphasizes opposition to war, and it educates students to draw voluntary contributions through a critical 
Figure 1. Global Peace Education Framework

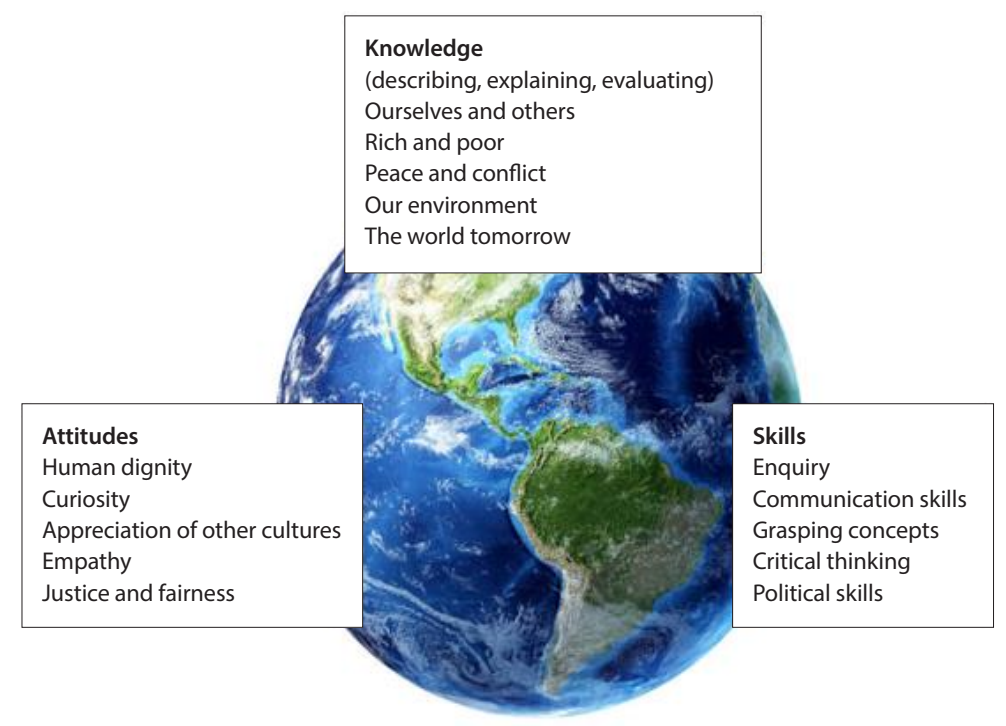

Source: Hicks and Holden 2007

understanding of the community to which the student belongs rather than directing students to unconditional war. It is very important for peace education to critically recognize and to educate students against socialization of sexism, racial discrimination, and social discrimination in the military culture. Therefore, peace education in South Korea should transform the competitive non-peaceful school culture into a cooperative and democratic education. In addition, in the sense of raising critical awareness of the global environment that influences education in Korea, peace education should be broadened from human rights education in daily life to global citizenship education (Kwon, Walker, and Kristjansson 2018).

As stated above, peace education has a comprehensive multilayered structure that encompasses peaceful understanding of oneself at the global level. The peace pedagogy of Friere underscores introspection and critical dialogue techniques as such. It is an intentional, multi-purpose educational activity that challenges the political and ethical fundamental culture of society and solves social conflict through nonviolence (McLaren and Lankshear 1994). Through this process, we should develop our ability to learn coexistence, nonviolence, and peaceful problem-solving techniques that everyone can use rather than attempt to solve problems by force. In peace pedagogy, questioning how a war is not to take place, to whom it is most concentrated, what efforts should be made to prevent it, and how to resolve cultural conflict and create a new culture of peace is constantly emphasized. This peace pedagogy not only fosters values and attitudes, but also 
builds a critical awareness of the structure of peace to nurture a balanced citizen. Its consequence is to have an optimistic view of future societies and enable citizens to take transformative social action (Hicks and Holden 2007).

Divided society refers to a violent society in which two different systems are hostile toward each other for reasons that may be political, economic, social, cultural, and religious, etc. (Sung 1983; Baek 1998). Whatever the cause of division, a violent society resulting from division creates more conflict. This system of division even leads to violent extremism on the basis of mental barriers, negative feelings and images about the other system, mutually exclusive identities, and conflicting belief systems (Kang 2000). Thus, in a society dominated by extreme dualism mediated by division, peace theory must be dominated by force because power must be built up to oppress the opponent. Therefore, the UN established a global agenda for peace education to prevent violent extremism in 2015 by seeking ways to combat this violent extremist terrorism (UNESCO 2016).

Peace education in a divided society refers to a collective effort to transform the hostile situation of division into peaceful coexistence (McGlynn, Zembylas, and Bekerman 2013). Peace education for overcoming division is the most peaceful means of achieving peace, as substantiated in post-conflict societies such as the former East and West Germany, Northern Ireland, and South Africa. For example, coexistence education attempted in some communities in Israel is characterized by Judeo-Arab coexistence (Bekerman 2007). Peace education in Northern Ireland is characterized by the Catholic-Protestant division of labor, education for mutual understanding, and integrated education to overcome violent division (Duffy 2000; Smith 2011; Niens, O'Connor, and Smith 2012). In Cyprus, peace education is characterized by multicultural coexistence education that transcends the boundaries between Turkish and Greek people (Hadjipavlou 2007). Anti-Apartheid education in South Africa (Bray and Joubert 2007) and political education in Germany provide us with some suggestions for peace education which aims to overcome social division (Lee and Song 2014). Peace education in a conflicted society emphasizes nonviolent, integrated education to identify the cause of division and to achieve a peaceful system through a righteous process for overcoming division.

In this sense, peace education for overcoming division of the Korean Peninsula should be a comprehensive holistic curriculum, as shown in Figure 2 , with the core system breaking down social division barriers to stimulate a peaceful nature against social evil caused by the structural violence of the division system and foster the competency to challenge conflict. First, as Kofi Anan mentions, the curriculum should aim to develop peaceful capacity and attitudes to construct human security, ultimately by recognizing knowledge related to division in a critical way, not by relying on military security (UNDP 1994). Second, from the viewpoint of humanitarianism, efforts to achieve 
Figure 2. Peace-Unification Education for Overcoming Division

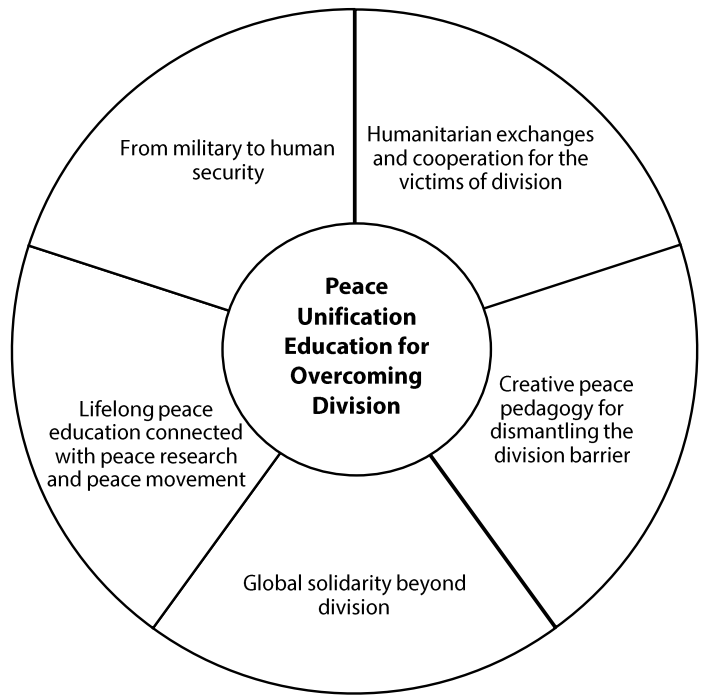

Source: Author

restorative justice for the mutual healing of victims and perpetrators of violence are required for peace education to overcome division. Supporting humanitarian exchanges and cooperation for the victims of division and linking them to the school curriculum is key to education for peace sensitivity. Third, a creative peace education curriculum is needed to collect social consensus on how to dismantle and reconstruct the division barriers such as the demilitarized zone (DMZ) in Korea, the peace wall in Northern Ireland, and the green line in Cyprus. This can be sublimated into division aesthetics. Fourth, since the division of Korean Peninsula is related to global division of the Cold War, peace education should include education for international understanding by seeking cooperation from neighboring countries beyond chauvinism grounded in national homogeneity (Kang and Kwon 2011). Fifth, peace education for overcoming division should be a lifelong learning process in which schools and civil society cooperate with each other to create a peace-friendly community. Peace awareness should not only be systematic learning through school education, but it should raise the sensitivity of change at all times through lifelong education (UNESCO 1997).

As substantiated in contact theory or multiculturalism, the absence and breakdown of communication caused by division deepens mutual prejudice and ignorance and leads to destabilization in the community by producing violence (McGlynn 2004; NI Mixed Marriage Association 2015). Therefore, for peace education on the Korean Peninsula to overcome division and build peaceful coexistence towards reunification, increases in nonviolent peaceful contact and expansion of exchanges and cooperation are needed. 


\section{Peace Process on the Korean Peninsula and Unification Education}

It can be asserted that inter-Korean relations can be classified into five stages (Im 2008; M. Kang 2013). Political changes affected the peace process on the Korean Peninsula, which in turn influences the nature of unification education. Several studies (Han 2001; Park 2006; An 2014; Kwon et al. 2014) categorized Korean unification education into three stages. However, in this article, the changes in unification education are divided into five periods, with three separate periods being delimited since the establishment of a democratic government in 1987, to investigate the interrelated nature of the peace process and unification education in Korea.

Hostile Anti-Communist Unification Education: From Liberation to 1972 Joint Statement

The first stage of the division of the Korean Peninsula was grounded in military confrontation in which the two Koreas sought unification by force. Unification education in the ROK was characterized by patriotism aimed at destroying communism and establishing a unified nation (Sung 1983). It was carried out in the curriculum containing quasi-military training and moral education. After the separate establishments of South and North Korea in 1948, the Korean War, which began on June 25, 1950, was the first attempt to form a unified Korea by force (Wada 1999). Since the 1953 Armistice Agreement, both Koreas have built a legacy of antagonism. In North Korea, anti-American and anti-capitalist unification education was conducted, while in South Korea, unification education was carried out under the banner of anti-communism and victory against communism (Cho 2007).

North Korea was not regarded as a sovereign state in the South. The two Koreas slandered each other while competing to widen their alliances on the world stage, and all mutual exchanges and recognition were prohibited by law. In the meantime, both sides devised destructive plots and suffered considerable damage in the process. The notion of a division contradiction was abused as the ideological basis to sustain undemocratic regimes (Baek 1998). In this process, North Korea developed the Juche idea of exclusive socialist nationalism, while President Park Chung-hee sought to consolidate the system through a constitutional amendment to sustain his power long-term in South Korea. InterKorean relations remained consistently blocked until the era of so-called détente emerged following the U.S. Nixon Doctrine announced in 1969. In particular, the United States and China began exchanges after a period of rapprochement. Then both Koreas announced the July 4 Joint Statement highlighting the principles of "independence, peace, and national unity" and stated that they would resolve the issue of division of the Korean Peninsula through their own efforts free from interference from great powers. In addition, the two sides agreed not to slander 
one another, to prevent inadvertent military incidents, to carry out numerous exchanges in various fields, to actively cooperate in seeking South-North Red Cross talks, to install a direct telephone line between Seoul and Pyongyang, and to operate a South-North Coordinating Committee (SNCC) co-chaired by Lee Hu-rak and Kim Young-joo (Moon 2015).

However, the July 4 Joint Statement did not lead to inter-Korean reconciliation and peace. The socialist constitutional framework based on the Juche idea was released in North Korea, and, in the South, the October Yushin (October Restoration) was announced in 1972, reinforcing Park Chung-hee's rule. This made both authoritarian regimes more politically rigid. Thus, unification education based on anti-communism in South Korea was strengthened crudely. In the end, the July 4 Joint Declaration principles of independence, peace, and national unity were neglected.

The first stage of unification education can be characterized as emotionally hostile anti-communist education and a representation of this is the slogan "I do not like the Communist Party" derived from the death of a nine year old boy, Lee Seung-bok, in a raid by North Korean soldiers into South Korea in December 1968. The direction of unification education towards anti-communism emphasized criticism of the communist ideology in North Korea, a so-called communist puppet, and consciousness for national security (Cho 2007), as described in the A Road to Unification by Defeating Communism textbook.

Whatever the fight, in order to win the fight, you have to be superior to your opponent. That is more so in the fight against the Communist Party. We must cultivate superior ability to compete with North Korean puppets in all aspects of politics, economy, military, culture, and social life...If we develop political, economic, and military capabilities that will overwhelm the Communist Party with national unity, we will be able to do what we do, either by means of a general election, or by the uprising of the North Korean compatriots, or by any other means, we will defeat the Communist Party and achieve the democratic unification we desire (Ministry of Education 1970).

Unification Security Education for the Maintenance of the Regime: From 1972 to 1987

In 1972, the July 4 Joint Declaration was secretly concluded and it seemed that unification was about to occur. In South Korea, however, due to the assassination of first lady Yuk Young-Soo by a Zainichi-Korean who sympathized with North Korea at the National Liberation Day ceremony on August 15, 1974, President Park Chung-hee proclaimed an emergency measure justifying "Korean Naturalization of Democracy," because he could not overcome the crisis facing the nation through Western democracy. Since integration of public opinion was considered too restricting, Park abolished direct presidential elections and severely restricted the authority of the National Assembly. The government 
suppressed the media, judicial circles, and universities, and arrested and imprisoned many citizens who resisted. Innocent civilians were also illegally arrested, sentenced, and even killed for distorting or slandering the Yushin Constitution. Under the highly controlled Yushin system, the basic principles of liberal democracy were denied and citizens were forced to live in political repression.

Despite tremendous resistance from the citizens, the government exaggerated the North Korean threat and built an atmosphere of fear under the principle of "reunification after construction." The government argued that criticism of the government benefitted North Korea and used strict national security laws to oppress critics. It feigned a crisis that the nation was in danger, making citizens monitor each other and held them in custody as soon as an impure act was discovered. Such oppression implies that Korean democracy was not on par with universal standards of democracy (Han 2014).

The insurgents who challenged this undemocratic regime were branded as pro-North and anti-unification forces and labeled as suspected subversives that divided the nation's power and hindered national development. Nevertheless, students in many universities continued crying out against the military dictatorship. Workers and the peasants struggled for the right to survive against the undemocratic regime. Members of opposition parties such as Kim Dae-jung and Kim Young-sam also participated in the opposition movements against the Yushin Constitution along with critical intellectuals. In the end, Park Chunghee was assassinated in 1979, and Korean society was expected to move forward toward democratization. However, General Chun Doo-hwan extended the military dictatorship following the accomplishments of Park Chung-hee. In midMay 1980 in Gwangju, innocent citizens were brutally slaughtered on the grounds that the nation was in crisis because of suspected North Korean subversives. However, people power against military dictatorship and violent repression of citizen progressed, and, in 1987, public outrage was sparked when young students Park Jong-cheol and Lee Han-yeol were killed on the way to a demonstration against the authoritarian government. As a result, the people's movement against the Chun Doo-hwan regime gained strength and finally brought an end to it in 1987.

Unification policy under the Chun Doo-hwan regime, which was an extension of the Yushin system, sought to strengthen the dictatorial regime based on strong military security. Obviously, education for unification was just an ideological extension of the state apparatus for maintaining the military dictatorship. Unification education in this period mainly focused on ideological indoctrination against communism and for military security while strengthening internal cohesion as shown below:

In order to break down the invasion of communism and achieve peaceful 
reunification, there must be a spirited determination of the people. It must be solidified...It is very important to make democracy a way of life in establishing national unity and unity of the people... On the other hand, since democracy is an idea developed in the West, the historical, cultural, and social conditions of our country should be taken into consideration in order to develop in accordance with the reality of our country... Our October Yushin is a measure to inculcate democracy in accordance with our constitution...The most important thing here is the conscious attitude of the people, making devoted efforts, that they should keep their historical mission and protect their peaceful reunification from the threat of invasion of communism (Ministry of Education 1973).

Unification Education for Peaceful Coexistence on the Korean Peninsula: 19882007

Following the successful people's movement to bring an end to the Chun Doo-hwan regime in 1987, the efforts of the democratization movement had a considerable influence on the unification movement. Nevertheless, just before the presidential election in 1987, the KAL bombing accident deepened negative sentiment against North Korea. After the Seoul Olympics in 1988, the Berlin Wall, the symbol of the Cold War, was demolished in 1989. As a détente atmosphere swept in, inter-Korean dialogue became a reality. At that time, confidence in unification by capitalist absorption became greater in Korea, as the process of absorption of East Germany by West Germany was observed. Consequently, a peaceful view of unification began to emerge (Seo 2010). In the process of forming a popular unification movement under the motto of "Go to North Korea, Come to our South," on March 25, 1989, Rev. Moon Ik-hwan, a standing adviser to the National Federation of Korean National Democratic Movements, visited Pyongyang on the invitation of Kim Il-sung. They said in a joint statement, "We must resolve the issue of reunification based on the three principles of independence, peaceful unification, and national unity," which are the values identified in the July 4 Joint Statement (Moon 1990). As soon as Rev. Moon returned home, he was arrested for violating the National Security Law; however, this incident can be said to have influenced the opening of the North to the non-government sector and instigated active exchange between North Korea and the Roh Tae-woo government.

Starting with the lead up to the 1988 Seoul Olympics, negotiations with North Korea progressed, and in 1991 North and South Korea were simultaneously admitted to the UN. During inter-Korean high-level talks, the 1992 Agreement on Reconciliation, Non-Aggression, and Exchanges and Cooperation between South and North Korea, also known as the Inter-Korean Basic Agreement, was concluded. A South-North Liaison Office was set up as a result, and the document also reaffirmed the three principles of the July 4 Joint Statement. These documents on inter-Korean relations serve as the basic guidelines for peace talks with North Korea. Although the Basic Agreement did not provide concrete 
Table 1. Inter-Korean Peace Process

\begin{tabular}{l|l|l}
\hline \hline \multicolumn{1}{c|}{ Date } & \multicolumn{1}{c}{ Document } & \multicolumn{1}{c}{ Principles } \\
\hline July 4, 1972 & $\begin{array}{l}\text { July 4 Joint } \\
\text { Statement }\end{array}$ & $\begin{array}{l}\text { Independence } \\
\text { Peace } \\
\text { National unity }\end{array}$ \\
\hline $\begin{array}{l}\text { December } \\
3,1991\end{array}$ & $\begin{array}{l}\text { Inter-Korean } \\
\text { Basic } \\
\text { Agreement }\end{array}$ & $\begin{array}{l}\text { Reconciliation } \\
\text { Nonaggression } \\
\text { Inter-Korean cooperation }\end{array}$ \\
\hline June 15, & $\begin{array}{l}\text { June 15 Joint } \\
\text { Statement }\end{array}$ & $\begin{array}{l}\text { Peaceful and gradual reunification with the strategy of one } \\
\text { country two systems } \\
\text { Family reunions } \\
\text { Humanitarian inter-Korean exchange } \\
\text { Regular top level official talks and summit meeting }\end{array}$ \\
\hline $\begin{array}{l}\text { October 4, } \\
2007\end{array}$ & $\begin{array}{l}\text { October 4 } \\
\text { Declaration }\end{array}$ & $\begin{array}{l}\text { Reconfirmation of June 15 Joint Statement } \\
\text { Military détente on Korean peninsula } \\
\text { Inter-Korean economic cooperation: railway and plans to } \\
\text { establish Kaesong Industrial Complex } \\
\text { Inter-Korean exchange and cooperation in the socio-cultural area } \\
\text { Joint support for the rights of overseas Koreans }\end{array}$ \\
\hline
\end{tabular}

Source: S. Kang 2013

measures, it can be said that the contents of the peace process toward overcoming the division are comprehensively covered (Chung 2011). The Kim Youngsam government seemed to have made considerable efforts toward peaceful unification following the Roh Twe-woo government's efforts as well (Im 2015).

Even so, when North Korea continued to develop nuclear weapons, the Kim Dae-jung government recognized that inclusive inter-Korean relations might lead to peaceful sustainability on the Korean Peninsula. Through the Sunshine Policy, North Korea was brought to the negotiating table and peace on the Korean Peninsula was realized (Kim 1997). The June 15, 2000 Declaration was a concrete plan for peaceful coexistence on the Korean Peninsula, building on the July 4 Joint Statement and the Inter-Korean Basic Agreement. This was rather a foreign policy derived from engaging and negotiating with the North, and, in fact, logically convinced the United States to make a positive approach toward North Korea (Chung 2018). This inclusive peace policy toward North Korea led the Roh Moo-hyun administration to continue the Sunshine Policy and conclude the October 4 Declaration, making the process of inter-Korean exchanges more concrete.

If we take a look at unification education in this period, it can be subdivided into the period of unification and security education during the Roh Tae-woo government, the period of seeking national unification education during the Kim Young-sam government, and the expansion and diversification of alternative 
perceptions of unification education during the Kim Dae-jung and Roh, Moohyun governments (Chun 2003; Cho 2007). Overall, the peace process on the Korean Peninsula had progressed from a human security point of view along with the détente mood within the international community starting from 1989 (Moon 2012). Unification education that conformed to this global trend was seen as having the character of peaceful coexistence. Contents of unification education started from the dimension of properly understanding North Korea based on the sentiments of Korea as one national community during the Roh Tae-woo government. However, as Kim Young-sam, Kim Dae-jung, and Roh Moo-hyun came to power, South Korea's unification education seemed to take on the trends of universal peace education (Han et al. 2016). In addition to the formal education curriculum, the negative image of North Korea was reduced through active learning connected to unification education in elective courses or through field trips to Mt. Kumgang, a site just across the DMZ in North Korea that was opened to tourists. As inter-Korean exchanges became more positive, the possibility of peaceful coexistence was discussed. Hyundai Chairman Chung Jooyoung at the time gifted 501 cows to North Korea and the flag of a unified Korea was flown at athletic events. However, unification education was still trapped in the framework of anti-communist education (Han 2010). As an interview with B shows, unification education centered on moral education for appealing to emotional unification based on national homogeneity and sympathy for poor North Koreans seemed to be far from peace education for moving beyond division (S. Kang 2013).

The atmosphere for unification has changed, and there is also room for talking about North Korea through elective courses and various club activities. However, even students who went on a school trip to Mt. Kumgang continue to interpret it negatively through the conventional anti-communism ideology. Overall, there is a limit to the development of perceptions of peaceful coexistence, as the historical perception of division is distorted, and there is a line of thought that defames North Korea because of pride in [South Korea's] capitalist development. And even if it is open, it is also inconvenient to take a revisionist point of view when we talk about North Korea or about division (Interview with B).

Back to Unification Security Education: From Mt. Kumgang Accident in 2008 to Dresden Speech

Despite the atmosphere of peace and reconciliation, the UN Security Council passed a resolution imposing strong sanctions against North Korea shortly after its first nuclear test in 2006. After the conservative Lee Myung-bak was elected president in 2007, the inter-Korean dialogue channel was cut off. In particular, after the September 11 terrorist attacks, a tough stance against North Korea was prevalent as the U.S. Bush administration strengthened the blockade of North Korea by defining North Korea as part of the axis of evil (Moon 2012). 
Nevertheless, as North Korea continued to develop nuclear weapons, it sought to deal with the nuclear issue through Six-Party Talks involving the Korean Peninsula's neighboring countries (Hong 2017). The hardline policy of North Korea and also that of South Korea ran parallel, and the hegemonic powers of the United States and China clashed causing a crisis on this Peninsula, particularly over THAAD (Terminal High Altitude Area Defense), definitively replaying the theory of peace by force (Song 2016).

In terms of the peace process, a series of dreadful incidents, including the Mt. Kumgang killing in 2008, the sinking of the ROK warship Cheonan in March 2010 that resulted in forty-one deaths, and the shelling of Yeonpyeong Island in November 2010 which led to four deaths, led to a virtual halt in North-South dialogue as the Lee Myung-bak administration issued the 5.24 Measures in 2010 declaring an end to inter-Korean physical and human exchanges. President Lee Myung-bak had advocated inter-Korean bilateralism at the beginning of his term, but these measures ignored the June 15 Joint Declaration and the October 4 Declaration. North Korea also counterattacked by labelling President Lee Myung-bak an insurgent. It was one of the lowest points in inter-Korean relations as mutual trust evaporated. In the end, tours to Mt. Kumgang and the Kaesong Industrial Complex, symbols of inter-Korean reconciliation, peace, and cooperation under the Sunshine Policy, were put on ice and any nongovernmental exchange was forbidden.

In the early days of 2013, the Park Geun-hye government organized the Presidential Committee for Unification Preparation for reviewing the abolishment of the 5.24 Measures, approved fertilizer aid to North Korea by NGOs, and offered a possible plan to allow inter-Korean exchanges between local governments and private organizations (Han 2015). However, these softening measures were limited, and the hardline measures against North Korea for continuing to develop and possess nuclear weapons remained rather firm. In principle, the Park administration's inter-Korean policy put on a strong emphasis on the military alliance with the United States to defend the nation from a North Korean military attack, and President Park Geun-hye declared in Dresden in 2014 a "Korean Peninsula denuclearization trust process" which stated the abandonment of nuclear weapons by North Korea was a precondition for interKorean coopeation or exchanges. It can be argued that there was no difference in the inter-Korean policies of the Lee Myung-Bak and Park Geun-hye governments (Moon 2015).

Unification education at the time was the same as security education in nature (Kim 2018). Despite use of the same term "peaceful unification" as in previous governments, according to the Guideline of Unification Education (Institute for Unification Education 2014), the volume and content of peaceful unification in school textbooks was reduced, and very negative depictions of North Korea as a regressive system or questions on human rights in North 
Korea were added according to an interview with A. Most unification education textbooks at that time criticized the Sunshine Policy and proceeded with a conservative security education based on negative perspectives of North Korea (Park 2017).

Because inter-Korean policy itself shifted toward the conservative wing, unification education is really difficult in terms of properly understanding North Korea. It used to be said that peace in words is peace for national prosperity and military defense. As previous governments developed a framework of unification education based on the Sunshine Policy for the last ten years, it was hard for these conservative governments to shift its orientation. Instead they made schools reduce unification class hours and consistently describe North Korea negatively. Since 2009, according to the Guideline of Unification Education, unification education has been less promoted in schools as well as in community education sites. It is difficult for teachers to discuss freely in the classroom because they are afraid of getting caught up in ideological disputes. This is a limitation of unification education from the perspective of peace education in general. (Interview with A)

Unification Education for Peace and Prosperity to Overcome Division: Following the Candlelight Revolution of 2017

With the impeachment of President Park Geun-hye in 2016, the conservative administration ended. The Moon Jae-in government, which was elected following the Candlelight Revolution, turned to an Open Door Policy for North Korea, and unification education was expected to change accordingly. In 2017, however, the domestic and international environment is making it difficult to implement a peace policy on the Korean Peninsula (Hong 2017).

Nevertheless, the direction of Moon Jae-in government to overcome the crisis on the Peninsula through peace without war is not in question. The Policy Innovation Committee of the Unification Ministry was formed in 2017, suggesting the end of the 5.24 Measure and the possible reopening of Mt. Kumgang tours and the Kaesong Industrial Complex. Since North Korea decided to participate in the Pyeongchang Winter Olympics in 2018, interKorean dialogue has been fast-paced. The Moon government has stressed inter-Korean policy and has emphasized cooperation with and intervention of ASEAN countries in resolving the issue on the Korean peninsula (Chung 2018). Most ASEAN countries have diplomatic ties with both Koreas at the same time. Amicable relationship with these countries is very important for peace and security on the Korean Peninsula, as they have begun to express their views on the North Korean nuclear issue as an Asian issue.

Since the issue of the Korean Peninsula is not only the problem of North and South Korea but the result of the international community, the viewpoint of education for international understanding aiming at peaceful coexistence based on amicable relations with neighboring countries is very important in 
Figure 3. Peace-Unification Education Framework

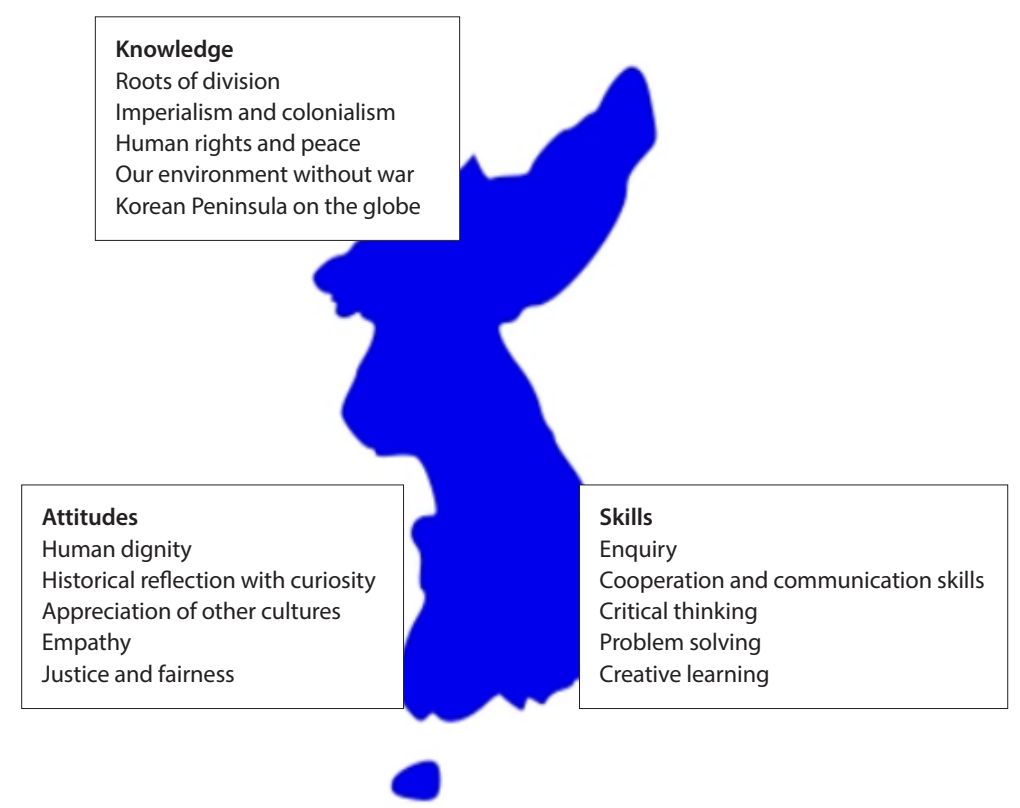

Source: Author

unification education (Han 2016). Since the direction of unification education has shifted from anti-communism to peaceful unification, the necessity of harmonizing the specificity and universality of unification education on the Korean Peninsula is being demanded these days. There is a need to listen to the argument by Park (2017) that since 2016, the task of unification education has been diversified beyond the ideological frame and should be seen from the perspective of world history. In addition, it is a challenge for unification advocates to take responsibility for making an opportunity for the youth to recognize the unification problem as "my problem" (Seo 2017). Therefore, according to the twenty-first century learning model proposed by United Nations Educational, Scientific and Cultural Organization (UNESCO), global division under the Cold War system should critically reflect the current predicament on the Korean Peninsula (UNESCO 1997). It should connect to education for international understanding, global citizenship education, and comprehensive peace education beyond division, which enables transformation of the culture of war and violence into a culture of peace for living together on a well-balanced Korean Peninsula. Unification education for peace and prosperity in Korea from the perspective of universal values, which was developed from the model of Hicks and Holden (2007), should be restructured into a holistic framework as shown in Figure 3. 


\section{Conclusions: Unification Education for Global Citizenship}

Since liberation, Korean politics have changed with various ideological deviations from right-wing conservative governments to the so-called left-wing progressive governments. Under conservative regimes, unification has been emphasized as a tool for the integration of domestic ideology, while the term of peace rather than unification was preferred during the periods of progressive governments (Han 2016). Therefore, the current administration that was swept in on the heels of the Candlelight Revolution will likely aim for inclusive peace unification education that resolves conflicts on the Korean Peninsula rather than sentimental moral education appealing to the inevitable national unification. The Moon Jae-in administration has established 100 projects for its agenda and divided them into five strategies. Under the fifth strategy of "Peace and Prosperity on for the Korean Peninsula," the administration has noted a project of "Expanding the Consensus on Unification, Promoting a Unification National Convention" (Moon Jae-in Government 2018). To this end, a Unification Center will be established in every metropolitan city by 2022 and there have been promises to support unification education, unification exhibition rooms, and North Korea defectors. Unification should not be viewed from the angle of the existing externalist national identity. Instead, unification education should provide hope for overcoming division and reflect such universal values as international cooperation, peace, conflict resolution, disarmament, and postcolonial discourses (Seo 2010; Hong 2012).

Today, unification education in schools is based on the newly revised seventh curriculum from 2015 and the Unification Education Support Act. This is done at the discretion of the teacher at each school according to the Unification Education Guideline of the year. Since its inauguration, based on the Unification Education Support Act, the imposition of emotional moral education and the value of free democracy has been more important than objective recognition of division and critical thinking about unification. Thus, on-going unification education should be developed into a holistic pedagogy in which unification research and the unification movement toward peace are combined within the peace-unification education framework, so as to transform the daily life of division into a peaceoriented life (Galtung 1975). This should be an inclusive peace education that seeks to change attitudes by bringing knowledge through the transformative pedagogy (Riley and Niens 2014). Such inclusive peace education connected to unification education should lead to education for international understanding or global citizenship that helps understand why the world is divided ideologically, economically, and politically, and why the Korean Peninsula became a pawn in the Cold War division.

According to contact theory (Allport 1954), reducing negative images such as stereotypes, prejudice, hostility, and discrimination, which result from segregation or separation in society, can be overcome through contact, which 
promotes mutual understanding. Thus, it is necessary to give equal status to both parties, build common goals, foster intergroup cooperation, and incubate mutual recognition of systems, laws, customs, and interpersonal interactions. If such efforts are not made, however, contact may even intensify negative images. Therefore, unification education alone cannot create a culture to overcome division. It must be accomplished under transformed political and social conditions. Unification education can be a tool to overcome division on the one hand, but it may also function as an ideological tool to maintain and reproduce the culture of separation on the other. To cope with the limit of the current model of unification education, the following suggestions are made based on the Figure 2.

First, the direction of overcoming the division of the Korean Peninsula should be re-contextualized from a perspective of military national security to one of comprehensive human security. To resolve the division of the Korean Peninsula, we should go beyond the framework of inter-Korean relations and educate students to be aware of the international context of global polarization or world division. Unification education also needs to be connected to education for international understanding that allows us to critically view both aspects of colonialism and imperialism, which links to the themes of the UN's Sustainable Development Goals (SDGs) as outlined in goals 4.7, 16, and 17. To this end, it should provoke an interdisciplinary debate on the universality of unification education as peace education for overcoming the division of the Korean Peninsula.

Second, "knowing the real North Korea" in unification curriculum should be based on the principle of friendly relations between people and states having different social and political systems, which was prescribed by UNESCO as education for international understanding in 1974. Because "knowing North Korea" used to emphasize the unfavorable relationship between the two sides, just sympathizing with North Koreans or criticizing human rights in North Korea on an emotional level can negatively impact efforts towards building a balanced partnership or peacebuilding on the Korean Peninsula (Ham 2015). Likewise, based on the premise of contact theory, the creation of mutual trust conditions on both sides should be carried out based on the five common denominators of peace, human rights, cultural diversity, sustainable development, and global citizenship, which UNESCO and other international organizations have set as universal standards (UNESCO APCEIU 2014). Since unification education is subject to change based on the shifts in the political and social environment, peace unification education should be understood as inclusive education to build democratic citizens beyond division.

Finally, if peace education is to overcome division, peace unification education should pursue the universal goals of today's global citizenship education, as stated in SDG 4.7, with a framework for lifelong learning in the twenty-first century that will nurture the capacity to live together. In this sense, 
the direction of unification education should be transformed from a moral education curriculum to a transformative holistic pedagogy. UNESCO suggested four pillars to which learning in twenty-first century education should aim: learning to know (knowledge), learning to be (values and attitudes), learning to do (participation), and learning to live together (coexistence); and these should be synthesized into unification education (UNESCO 1997). In order to disseminate such pedagogical methods, international organizations, civil society groups, universities, and other governmental organizations such as teacher organizations, unification education institutes, and training institutes should all cooperate for peace beyond division.

It is unification education as peace education which will overcome division and identify whether it is possible to solve the problems of dismantling warfare by nonviolent and peaceful ways. Therefore, unification education should be positioned as peace education that empowers peacebuilding for overcoming the division against the conspiracy of the political groups who seek to utilize unification as an ideological tool for maintaining the system of division.

\section{References}

Allport, G. W. 1954. The Nature of Prejudice. Cambridge, MA: Perseus Books.

An, Seung-Dae. 2014. "A study on the transitions and a new direction of unification education." [In Korean.] The Institute for Korean Culture 57: 135-152.

Baek, Nack-Chung. 1998. The Tottering System of Division. [In Korean.] Seoul: Changbi.

Bekerman, Zvi. 2007. "Developing Palestinian-Jewish bilingual integrated education in Israel: Opportunities and challenges for peace education in conflict societies." In Addressing Ethnic Conflict Through Peace Education: International Perspcetives, ed. Zvi Bekerman, and Claire McGlynn, 91-106. New York: Palgrave Macmillan.

Bray, E., and R. Joubert. 2007. "Reconciliation and peace in education in South Africa: The constitutional framework and practical manifestation in school education." In Addressing Ethnic Conflict Through Peace Education: International Perspcetives, ed. Zvi Bekerman, and Claire McGlynn, 49-59. New York: Palgrave Macmillan.

Cho, Jeong-Ah. 2007. "The issues and tasks in education for national integration." [In Korean.] International Journal of Korean Unification Studies 16 (2): 285-306.

Chun, Hyo-Kwan. 2003. "Softened unification education, issues and positions." [In Korean.] Contemporary North Korea Studies 6 (2): 167-185.

Chung, Hyun-Back, and Jung-Soo Kim. 2007. Understanding Unification Education towards Peace. [In Korean.] Seoul: Unification Education Center of the Ministry of Unification.

Chung, Jin. 2016. Classroom Management Guide for Restorative Life Education. [In Korean.] Namyangjoo: Peace building.

Chung, Kyu-Sup. 2011. Inter-Korean Basic Agreement: Its Meaning and Evaluation. [In Korean.] Seoul: National Institute of Unification.

Chung, Wook-Sik. 2018. “Trump administration and Korea-America-Japan.” [In Korean.] 
Asia Culture January and February: 177-194.

Cumings, Bruce. 1986. The Origins of the Korean War. New York: Random House.

Duffy, Terence. 2000. "Peace education in a divided society: Creating a culture of peace in Northern Ireland." Prospects 30 (1): 15-29.

Galtung, Johan. 1975. Essays in Peace Research. Oslo: PRIO monographs.

Galtung, Johan. 1985. "The Cold War, peace and development: A comparison between the Atlantic and Pacific theatres." https://www.transcend.org/galtung/papers/The\%20 Cold\%20War,\%20Peace\%20and\%20Development-A\%20Comparison\%20of\%20 the\%20Atlantic\%20and\%20Pacific\%20Theaters.pdf (accessed May 7, 2018).

Galtung, Johan. 1996. Peace By Peaceful Means: Peace and Conflict, Development and Civilization. London: Sage.

Gyeonggi Metropolitan Education Authority. 2011. "Charter of Gyeonggi Peace Education." [In Korean.] http://blog.daum.net/ken_news/6049057 (accessed May 16, 2018).

Hadjipavlou, M. 2007. "Multiple realities and the role of peace education in deep-rooted conflicts: The case of Cyprus." In Addressing Ethnic Conflict Through Peace Education: International Perspcetives, ed. Zvi Bekerman, and Claire McGlynn, 35-48. New York: Palgrave Macmillan.

Ham, Kyu-Jin. 2015. "A study of critical issues and solutions in the unification education of elementary school." [In Korean.] Legislation and Policy 7 (1): 83-105.

Ham, Seok-Heon. 2003. The Korean History by its Meaning. [In Korean.] Paju: Hangilsa.

Han, Hong-Ku. 2010. A History of This Current Moment. [In Korean.] Seoul: Hankyoreh Publication Co.

Han, Hong-Ku. 2014. Yushin: An Age for the Only One Man. [In Korean.] Seoul: Hankyoreh Publication Co.

Han, Man-Kil. 2001. Theory and Practice of Unification Education. [In Korean.] Paju: Educational Science Co.

Han, Man-Kil, ed. 2016. Education for Making Unification. [In Korean.] Paju: Education and Science Co.

Han, Young-Sup. 2015. Peace and Military Control in Korean Peninsula. [In Korean.] Seoul: Parkyoungsa.

Hong, Suck-Hyun. 2017. Paecemaking in Korean Peninsula. [In Korean.] Paju: Nanam.

Hong, Suck-Ryul. 2012. Hysteria of Division. [In Korean.] Paju: Changbi.

Hicks, David, and Cathie Holden. 2007. Teaching the Global Dimension. London: Routledge.

Im, Tobin. 2008. "How has administrative philosophy changed in Korea? A historical approach to governing philosophies appearing over the last 60 years." [In Korean.] Korean Journal of Political Administration 46 (1): 211-251.

Im, Dong-Won. 2015. Peace Maker: The 25 Years of Inter-Korean Affairs in North Korea Nuclear Weapons. [In Korean.] Paju: Changbi.

Institute for Unification Education. 2014. "Guideline of unification education." [In Korean.] http://lib.rda.go.kr/search/searchDetail.do?ctrl=000000189991 (accessed May 16, 2018).

Jin, Jing-Yi. 2018. "Problems of Korean peninsula and war and peace in the Northeast Asia." [In Korean.] Asia Culture January and February: 27-42.

Kang, Mangil. 2013. Suffering of Division and History of Unification Prospect: The Modern History of the Age of Division towards Unification. [In Korean.] Seoul: Seonmin. 
Kang, Soon Won. 2000. Education for Peace and Human Rights. [In Korean.] Seoul: Hanwool.

Kang, Soon Won. 2013. "How peace education has tried to overcome the division of Korea into two nations: Practicing peace-reunification education in schools." In Peace Education from the Grassroots, ed. Ian Harris, 151-171. Charlotte, NC: Information Age Publishing.

Kang, Soon Won, and Soonjung Kwon. 2011. "Reunification education viewed from peace education of Northeast Asia." Korean Journal of Comparative Education 21 (3): 95126.

Kim, Dae-jung. 1997. Kim Dae-jung's Three-stage Approach to Korean Reunification: SouthNorth Confederal Stage. Los Angeles: University of Southern California.

Kim, Jong-Soo. 2018. "Officials of the ministry of unification are wallowing in sense of shame." [In Korean.] Sisa-In, January 23. http://www.sisain.co.kr/?mod=news\&act=ar ticleView\&idxno=31080 (accessed May 16, 2018).

Kim, Ku. 2005. Baekbum Diary. [In Korean.] Paju: Dolbegae.

Kim, Sung-Jae. 1988. The Reality of Division and Christian People's Education. [In Korean.] Seoul: Korean Institute of Theology.

Kwon, Jaeil, Kyungja Choi, Myungsook Cho, and Sungchoon Park. 2014. "A study of peaceunification education strategy for peace and co-prosperity." [In Korean.] SNU Policy Research Paper of the Committee for Unification Preparation.

Kwon, Soonjung, K. Kristjansson, and D. Walker. 2016. "Misery in dark shadows behind the high achievement scores in South Korean schooling: An ethnographic study." Educational Review 69 (2): 201-217.

Kwon, Soonjung, D. Walker, and K. Kristjansson. 2018. "Shining light into dark shadows of violence and learned helplessness: Peace education in South Korean schools." Journal of Peace Education 15 (1): 24-47.

Lee, Dong-Ki, and Young-Hoon Song. 2014. "A study of action plan for peace-unification education.” [In Korean.] UNESCO Policy Research. Seoul: KNCU.

Lee, Samuel. 2017. The Search for Social Philosophy towards Reformation of the Social Reality. [In Korean.] Seoul: Philosophy and Reality Co.

Mamdami, Mahmood. 2012. Define and Rule: Native as Political Identity. Cambridge, MA: Harvard University Press.

McGlynn, Claire. 2004. "Education for peace in integrated schools: a priority for Northern Ireland?" Child Care in Practice 10 (2): 85-94.

McGlynn, Claire, Michalinos Zembylas, and Zvi Bekerman, eds. 2013. Integrated Education in Conflicted Societies. New York: Palgrave Macmillan.

McLaren, Peter, and Colin Lankshear, eds. 1994. Politics of Liberation. Paths from Freire. London and New York: Routledge.

Ministry of Education. 1970. The Road to Unification by Defeating Communism. For Middle Schools. [In Korean.] Seoul: National Textbook Publisher.

Ministry of Education. 1973. The Road to Unification by Defeating Communism 3. For Middle Schools. [In Korean.] Seoul: National Textbook Publisher.

Ministry of Unification. 2013. "Unification Education Support Act." [In Korean.] http:// www.law.go.kr/lsInfoP.do?lsiSeq=142938\&efYd=20140214\#0000 (accessed May 16, 2018).

Moon, Chung-In. 2012. The Sunshine Policy: In Defense of Engagement as a Path to Peace in 
Korea. Seoul: Yonsei University Press.

Moon, Chung-In. 2015. The 70 Years of Division: Asking a road to 15 June (Sunshine policy) again. [In Korean.] Seoul: Yonsei University Press.

Moon, Ik-Hwan. 1990. Wishing to Go on Foot. [In Korean.] Seoul: Silcheonmoonhacksa.

Moon, Jae-In. 2017. "Speech on the Day of Independence." [In Korean.] http://www1. president.go.kr/articles/524 (accessed May 16, 2018).

Moon Jae-in Government. 2018. “Administration projects." [In Korean.] Accessed May 16. http://www1.president.go.kr/government-projects.

Niens, Ulrike, Una O'Connor, and Alan Smith. 2012. "Citizenship education in divided societies: teachers' perspectives in Northern Ireland." Citizenship Studies 1 (1): 1-14.

NI (Northern Ireland) Mixed Marriage Association. 2015. Both Sides Now. Belfast: Nova Print \& Design.

Park, Boyoung. 2004. "Unification education from the perspective of peace education." [In Korean.] Journal of Future Education 17 (2): 55-70.

Park, Chan-Seok. 2006. The Establishment and Process of Unification Education. [In Korean.] Paju: Korean Academic Information.

Park, Chan-Seok. 2017. "The status and challenges of unification education in Republic of Korea after 2016.” [In Korean.] Moral and Ethics Education 54: 265-288.

Reardon, Betty. 1988. Comprehensive Peace Education: Educating for Global Responsibility, New York: Teachers College Press.

Reardon, Betty. 2001. Education for a Culture of Peace in a Gender Perspective. Paris: UNESCO.

Reilly, Jacqueline, and Ulrike Niens. 2014. "Global citizenship as education for peacebuilding in a divided society: Structural and contextual constraints on the development of critical dialogic discourse in schools." Compare: A Journal of Comparative and International Education 44 (1): 53-76.

Seo, Bohyuk. 2010. Democratization Movement of Korea Revised: Origin, Process and System. [In Korean.] Seoul: Korea Democracy Foundation.

Seo, Jungbae. 2017. "Core element of unification education is to support drawing dreams of participatory experiencing future of unification." [In Korean.] Unification Korea 408 (December): 32-35.

Smith, Alan. 2011. "Education and peacebuilding: From 'conflict-analysis' to 'conflict transformation'?” FriEnt, July 15. https://www.frient.de/news/details/news/educationand-peacebuilding-from-conflict-analysis-to-conflict-transformation/ (accessed May 7, 2018).

Song, Dae-Sung. 2016. Let's Have Our Nuclear. [In Korean.] Seoul: Kiparang.

Sung, Nae-Woon. 1983. People's Education in the Age of Division. [In Korean.] Seoul: Hackminsa.

UNDP (United Nations Development Programme). 1994. Human Development Report. New York: Oxford University Press.

UNESCO (United Nations Educational, Scientific and Cultural Organization). 1997. Treasure Within: Report to UNESCO of the International Commission on Education for the Twenty-first Century. Paris: UNESCO.

UNESCO (United Nations Educational, Scientific and Cultural Organization). 2016. A Teacher's Guide on the Prevention of Violent Extremism through Education. Paris: UNESCO. 
UNESCO (United Nations Educational, Scientific and Cultural Organization) APCEIU (Asia-Pacific Center of Education for International Understanding). 2014. "Global citizenship education: An emerging perspective.” http://unesdoc.unesco.org/ images/0022/002241/224115E.pdf (accessed May 7, 2018).

Wada, Haruki. 1999. Korean War. [In Korean.] Translated by Dong-Man Seo. Seoul: Changjack and Bipyung Co.

Soon-Won Kang is a professor in the department of Child Psychology at Hanshin University, South Korea. She obtained her Ph.D. at Ewha Woman's University, South Korea with the dissertation of "Analysis of Over-education in the 1970s from the Perspective of Political Economy" in 1988. She was dean of the Graduate School of Education, Hanshin University, a member of International Advisory Committee of UNESCO APCEIU, a member of the Presidential Advisory Committee for Education during the Kim Dae-jung government, President of the Korean Society of Education for International Understanding, and is now President of the NGO Conflict Resolution and Dialogue. She has written books such as Education in the Capitalist Society, Political Economy of Korean Education, Education for Peace and Human Rights, Peer Mediation, A Journey to Alternative Schools, Sociology of Education retrospectively thing, A Journey to the integrated schools in Northern Ireland. Email: kangsw@hs.ac.kr. 